\title{
THE USE OF MISTAKE BUSTER TECHNIQUE TO IMPROVE THE STUDENTS' WRITING SKILL
}

\author{
Penggunaan Teknik Mistake Buster Untuk Meningkakan Keterampilan \\ Menulis Siswa
}

\section{Bahrun Amin}

English Education Department, Faculty of Teacher Training and Education Muhammadiyah University of Makassar

\begin{abstract}
This research aimed to find out whether or not Mistake Buster Technique is effective to be used in writing a recount composition and find out the extent to which Mistake Buster Technique improve the ability of students in writing a recount composition for the Second Grade Students. A quasi experimental design was employed with two classes of the second graders at one school in Makassar selected purposively as sample. The data were obtained through a pre-test and a post-test. The writing assessment was adopted from Depdikbud (1996) covering language use and organization. The findings were analyzed statistically sing independent t-test procedure.

The research findings indicated that the use of Mistake Buster Technique could improve the students " writing skill on language use and organization in writing recount composition. It was proved by the students' mean score of experimental class in pre-test was (10.125) and in post-test was (65.5). While the mean score of control class in pre-test was (9.375) and in post-test was (41.125). The findings of this research shows that the value of t-test in the posttest is higher than t table $(4.28>2,02)$. It means that there was significant difference of the students' writing skill on language use and organization in writing recount composition before and after being taught using Mistake Buster Technique at the Second Grade of SMPN 33 Makassar.

The statistical computation showed that Mistake Buster Technique was likely effective in improving the students' writing skill on language use and organization in writing recount composition.
\end{abstract}

Keywords: Mistake Buster Technique, recount composition, writing.

Writing skill is an important part of communication. Nowadays, good writing skill allows us to communicate our message with clarity and ease to a far larger audience than through face-to-face or telephone conversations. We might be called upon to write a report, plan or strategy at work; write a grant application or press release within a volunteering role; or we may fancy communicating our ideas online via a blog.

There are many kinds of writing types, such as descriptive, recount, 
narrative, exposition, procedure, anecdote, news item, and discussion. One of them is recount. Recount is the text telling the reader what happened. It retells a past event. It begins by telling the reader who was involved, what happened, where this event took place and when it happened (Pardiyono, 2007: 63). This kind of writing has been one of subjects in the syllabus of Junior High School level. So, this text should be able written well by the students.

As a response to the aim above, an observation at SMPN 33 Makassar was conducted to get the first data about students' writing skill. The result of the observation shown that the students had not yet understand well how to write recount composition by using simple past form in well organization.

The case above proves that although writing is very important for us, it is a difficult subject especially for the student. The reason is according to Heaton in his book "Writing English Language Test" (1975:138); Writing skill are more complex and difficult to teaching, requiring, and mastering not only of grammatical and rhetorical devices but also conceptual and judgment, because of the difficulties of writing, some efforts have been done to solve the problem.

Furthermore, the problem is not only focused on the writing skill actually. The second place is about class management. The teacher's way in transferring the material is important to help students' understanding. This will be a challenge for the teacher to find out the way how the students can learn writing easily and exciting. Brown (1994: 160) states that a good teacher has to be able to make the classroom live. He has to conduct some efforts to employ various methods and techniques, utilize some media and motivate his students in learning English including writing skills effectively and efficiently. Thus, the interesting technique should be applied in teaching process.

In this sense the writer tries to use "Mistake Buster Technique" as one of the interesting techniques in teaching writing. This technique will bring the students act as "mistake corrector". It can make the students get excited, giving our students a sense of accomplishment and can help us to check our students understanding of a grammar point. Therefore, this technique is really useful for reinforcing and improving the productive skill, such as writing and pronunciation. 


\section{What is Writing?}

Meyer in Sarlin (2009:8) defines writing is thinking on paper or mood at work finding facts, seeing relationship, testing the truth of them, reaching conclusion and forming opinion. Meanwhile, Brummer and Clark (2008:4) say that the writing is making of letters or characters that constitute readable matter with the intent to convey meaning.

Leo (2007:01) states writing as a process of expressing ideas or thoughts in words should be done at leisure time. It does not mean that writing is the most difficult subject to be learned. He says that all students can be taught to express their ideas.

Byrne (1980:24) defines that writing is a primary means of recording speech, even though it must be acknowledged as a secondary medium of communication. The aims of writing are:

a) Desire to explain or to inform

b) Desire to tell something as it was looked and heard

c) Desire to tell something about something happened

d) Desire to convince someone

Based on some definitions above, the writer concludes that writing is kind of activity where the writer expresses all the ideas in her mind on the paper start form words to sentences, sentences to paragraph, and from paragraph to essay or process of transferring someone has in his/her mind into written language to give information to the readers.

\section{The Nature of the Writing Skill}

Broughton et. al (1975:116) say that when we write, unlike when we talk, we are engaged in an activity which is usually at the same time both private and public. It is private because the act of composition is by its nature solitary, but it is public in that most writing is intended for an audience, often one which is extremely difficult to define. The act of writing differs from that of talking in that it is less spontaneous and more permanent, and the resources which are available for communication are fewer because we cannot-as we do in conversation-interact with the listeners and adapt as we go along. For this reason 
the conventions of writing tend to be less flexible than those of conversation, and the language which is used tends to be standardized. If the goal of the English teacher is to enable students to produce fluent, accurate and appropriate written English, there are a number of aspects which need to be considered. These are:

1. Mechanical problem with the script of English;

2. Problems of accuracy of English grammar and lexis;

3. Problem of relating the style of writing to the demands of a particular situation.

4. Problems of developing ease and comfort in expressing what needs to be said.

\section{Writing Components}

Jacob et. al (1981: 31) point out five significants components in writing. These are content, organization, vocabulary, language use and mechanic. The detail explanations are as follows:

\section{a. Content}

The content of writing should be clear for the readers so that the readers can understand the message conveyed and and gain information from it. In order to have a good contents writing, its contents should be well unified and completed. This term is usually known as unity and completed. This term is usually known as unity and completeness, which become characteristic of good writing.

\section{b. Organization}

In organization of the writing, the writer focuses on how arrange and organize the ideas chronologically. They also should present their ideas based on the order which flow from the beginning to the end. There are many ways used to organized or arrange the writing. This organization is mainly recognized as order.

\section{c. Vocabulary}

Vocabulary is one of the language aspects dealing with the process of writing study. In the process of writing, the writer always think about putting words into sentences and then putting sentences into paragraph until they can create a piece of writing. So, mastering word choice can help us to develop our writing.

\section{d. Language Use}


Language use in writing involves correct usage of the rules of language or grammar. It focuses on verbs, noun, agreement. Specific nouns and strong verbs give a reader a mental image of description. This specific noun can be characterized by using modifier of adjective, adverbs, and participle forms. A modifier can be phrase. There are many opportunities for errors in the use of verbs and mistake in arrangement are very common.

\section{e. Mechanics}

Mechanics in writing deal with capitalization, punctuation and spelling appropriately. This aspect is very important since it leads reader to understand to recognize immediately what the writer means to express definitely. The use os favorable mechanics in writing will make readers easy to understanding the conveying ideas other message stated in the writing.

\section{Composition}

Littell (1981) states that a composition is a group of paragraphs dealing with one main idea. In some ways, a composition is similar to a paragraph. Both deal with only one main idea that may be real or imaginary. Both have a logical beginning, middle, and end and are organized by the used of transition. Although a topic for a composition is one that is too broad for a single paragraph, it must be also be limited to the scope of one main idea.

The first paragraph is the introduction. In it, state your topic clearly and prepare your readers for what is to follow. The middle paragraphs are the body of a composition. In a narrative composition, the body contains the events of a real or imaginary story. In descriptive composition, it contains the sensory details of a word picture. In an explanatory composition, the body contains direction that explain a process, reasons that support an opinion, or detail that develop a definition. The final paragraph of a composition is the conclusion. Here you summarize your main idea. You may want to add a little.

\section{Recount Text}

Recount is a report of even or activity in the past. It is to inform or to entertain the readers. Structure of the text:

1. Orientation give information about who, what, when and where. 
2. Report of event or activity (in chronological order)

\section{Recount}

a. The Meaning of Recount

Recount is the text telling the reader what happened. It retells a past event. It begins by telling the reader who was involved, what happened, where this event took place and when it happened (Pardiyono, 2007: 63). At an Online Education Journal, writing recount is said that it may be a reorientation at the end. It summarizes the event in the order in which they happened (chronological order). Recount is written to retell events with the purpose of either informing or entertaining their audience (or both).

b. Purpose

Derewianka (2004: 18) states that the purpose of a recount is to list and describe past experiences by retelling events in the order in which they happened (chronological order). To achieve its purpose, the text will move through a different set of stages: a) an orientation letting the reader knows who is involved, where, when, etc. b) the retelling of a series of events in chronological sequence. Recounts are written to retell events with the purpose of either informing or entertaining their audience (or both). Frequent use is made of words, which link events in time, such us next, after, when then, after, before, first, at the same time. It describes events, so plenty of use is made of verbs (action words), and of adverbs (which describe or add more details are often chosen to add interest or humor to the recount).

c. Types of Recount

1) Personal Recount; these usually retell an event that the writer was personally involved in.

2) Factual Recount; recording an incident, e.g. a science experiment, police report.

3) Imaginative Recount; writing an imaginary role and giving details of events, e.g. A day in the life of a pirate. (Derewianka, 2004: 16" Exploring How Texts Work").

d. Features of Recounts and Conventions 
The recount has a title, which summarizes the text. Past tense verbs are used, and frequent use is made of words which link events in time, such as next, later, when, then, after, before, first. Recounts describe events, so plenty of use is made of verbs (action words), and of adverbs (which describe or add more detail to verbs). (Derewianka, 2004: 16" Exploring How Texts Work").

e. Structure; a recount has a title, which usually summaries the text specific participants (Mum, the crab).

The basic of recount consist of three parts:

1) The setting or orientation - background information answering who? when? where? And why?

2) Events are identified and described in chronological order.

3) Concluding comments express a personal opinion regarding the events described. (Derewianka, 2004: 16" Exploring How Texts Work").

\section{Mistake Buster Technique}

According to Huynh (2003), Mistake Buster Technique works well with beginner to high intermediate students. Step-by-step explanation of how to employ this Technique will be given to help interested teachers adapt it for their own classes.

This Technique can bring forth several benefits. For instance, by switching the role of the "mistake corrector" we will observe the students get excited. The level of excitement is even increased when the class is divided into two each other in finding and correcting the mistakes. Another benefit is that they have the opportunity to identify the possible mistake themselves instead of the teacher telling them what the mistakes are, thus giving them a sense of accomplishment. This Technique can also help the teacher checks the students' understanding of grammar point or comprehension of a reading task. It can be used to reinforce and improve their production skill such as writing and pronunciation. Last but not least, it is nonthreatening and fun which is one the best conditions for learning to take place.

\section{Preparation}


Huynh (2003) gives us two steps as a preparation before doing the teaching activity. The detail explanation as follows;

\section{a. Choosing a Mistake Category}

Select a mistake category that is pertinent to the focus of the lesson being taught. For the purpose of demonstrating the employment of this Technique, the past tense of irregular and regular verbs will be used as an illustration.

\section{b. Preparing the Mistake (Regular and Irregular Verbs in the Simple Past} Tense)

The wrong verbs to be found and corrected by the students can be prepared in the form of a verb list, in Short sentences, in long sentences or in a narrative.

\section{Sample Activity}

Huynh (2003) shows how the "Mistake Buster" is employed to check students' ability to use regular and irregular verbs in the simple past tense as follows:

\section{Step 1. Warm Up: (A Verb List can be Used)}

a. Tell students they are going to have an activity to review the Simple Past Tense.

b. Divided the class into two teams and tell them they are going to compete in the activity.

c. Make two columns on the white board and ask students to fill the left column with many verbs in the Present Tense.

d. Tell them they have to find the Past tense forms for all the verbs. They have to raise their hands quickly to get the permission to give an answer. For each correct answer, the team will score ten points.

e. Begin the activity and add up the scores for each team when all the verbs have been changed to the Simple Past Tense.

\section{Step 2. (Short Sentence and Long Sentences can be Used)}

a. Tell students that they have to listen to short sentences and then long sentences to find the mistakes in the verbs and correct them by putting them in the Simple Past Tense. 
b. Start reading one sentence at a time. Repeat the sentence if they did not understand it the first time.

c. Students have to raise their hands quickly to get the permission to give an answer. For each correct answer, the team will score ten points.

d. Keep scores and add them up after all sentences have been read and corrected.

\section{Step 3. (A Narrative can be Used)}

a. Tell students they are going to listen to a narrative and write down the verbs they think are wrong.

b. Read the narrative at a normal speed once.

c. Read it again if necessary.

d. They have to raise their hands quickly to get the permission to give an answer.

e. Ask them to say out loud the wrong verbs they heard and the correction as well.

f. Keep score and add them up when all the verbs have been corrected,

\section{Step 4. Wrap Up}

a. Praise Students for their efforts.

b. Review important points or give more explanation if necessary

\section{RESEARCH METHODOLOGY}

\section{A. Research design}

This research employed quasi experimental research. The writer used the experimental and control group, where the experimental group was treated by using Mistake Buster Technique and control group was treated without the experimental technique. This research focused on nonequivalent control group design since control group and experiment group was not chosen randomly. The two existing groups took a pretest-treatment-posttest. The formula of this design was shown in table 3.1 as follows:

Table 3.1

The Experimental Design

\begin{tabular}{|c|c|c|c|}
\hline Groups & Pretest & Treatment & Posttest \\
\hline Experimental & $\mathrm{O}_{1}$ & $\mathrm{X}_{1}$ & $\mathrm{O}_{2}$ \\
\hline Control & $\mathrm{O}_{1}$ & $\mathrm{X}_{2}$ & $\mathrm{O}_{2}$ \\
\hline
\end{tabular}

$\mathrm{O}_{1} \quad=$ Pretest

$\mathrm{O}_{2}=$ Posttest

$\mathrm{X}_{1}=$ Using Mistake Buster Technique

$\mathrm{X}_{2}=$ Using Audio Visual Method

B. Population and sample 


\section{Population and Sample}

The population of this research was the second grade students of SMPN 33 Makassar year 2013/2014, which consisted of seven classes. Each class contained approximately 20 students, thus the total population was 140 students. Applying purposive sampling technique, there were two chosen classes of the second grade students. The classes were class VIII IT 2 as the control class VIII A as the experimental class. The numbers of the students of each class was 20, thus the total numbers of the sample was 40 .

\section{Variables of the Research}

There were two variables in this research namely: independent and dependent variables. Independent variable was the use of Mistake Buster Technique in teaching recount composition and dependent variable was the improvement of the students' writing skill.

\section{The Instrument of the Research}

The instrument of the research used written test that consisted of two types: error correction and writing a recount composition test. Each test used to examine the students' writing skill of recount composition in pre-test and post-test.

The pre-test intends to find out the students' prior knowledge of writing recount composition while the post-test was intended to find out the students' improvement in writing recount composition after the treatment was given. The content of pretest is the same as the content of the posttest.

\section{E. Procedure of Collecting Data}

Technique of data collection in this research is as follows:

\section{Pre-test}

Before giving treatment, the writer applied a pre-test to sample group. The pre-test was intended to know the students' prior knowledge about recount composition before giving treatment. In this case, the students were given a number of questions. Those questions were error correction, and writing a recount composition test.

2. Treatment 
The sample treated by using Mistake Buster Technique. In this case, the students were asked to find out the incorrect word in each step of mistake buster technique. In addition, this learning process obligated the students study in group activity. The treatment was conducted five times

\section{Post-test}

After doing treatment, the post-test was given as well as the pre-test. This spent 80 minutes times. The post-test aimed to find out the improvement of students in learning recount composition by using Mistake Buster Technique.

\section{F. Technique of Data Analysis}

In technique of data analysis, the researcher analyzed data quantitatively. The quantitative analysis was used to analyze the two components in writing test. The components of good writing as follow: Language use (grammar) and Organization.

Scoring and classifying the students' ability into the following criteria:

1. Scoring Criteria of Language Use for Recount Composition:

Table 3.2

Language Use (Past Tense)

\begin{tabular}{|l|c|l|}
\hline \multicolumn{1}{|c|}{ Classification } & Score & \multicolumn{1}{|c|}{ Criteria } \\
\hline $\begin{array}{l}\text { Excellent to very } \\
\text { good }\end{array}$ & $39-50$ & $\begin{array}{l}\text { Effective complex construction, few errors of } \\
\text { agreement, tense, number, word/order function, } \\
\text { article, pronoun and preposition }\end{array}$ \\
\hline Good to average & $27-38$ & $\begin{array}{l}\text { Few errors of agreement, tense, number, } \\
\text { word/order function, article, pronoun and } \\
\text { preposition meaning confused or obscured }\end{array}$ \\
\hline Fair to poor & $16-26$ & $\begin{array}{l}\text { Dominant by errors of grammar, cannot be } \\
\text { understood and evaluated }\end{array}$ \\
\hline Very poor & $0-15$ & $\begin{array}{l}\text { Virtually no mastery of sentence consist rules, } \\
\text { etc }\end{array}$ \\
\hline
\end{tabular}

(Depdikbud, 1999:6)

2. Scoring Criteria of Organization for Recount Composition:

Table 3.3

\section{Organization}

\begin{tabular}{|l|c|l|}
\hline \multicolumn{1}{|c|}{ Classification } & Score & \multicolumn{1}{c|}{ Criteria } \\
\hline Excellent to very good & $39-50$ & $\begin{array}{l}\text { Have a clear beginning, middle, and end; } \\
\text { each idea is grouped orderly and logically. }\end{array}$ \\
\hline Good to average & $27-38$ & Have a clear beginning, middle, and end; \\
\hline
\end{tabular}




\begin{tabular}{|l|c|l|}
\hline & & $\begin{array}{l}\text { some ideas are not grouped orderly and } \\
\text { logically. }\end{array}$ \\
\hline Fair to poor & $16-26$ & $\begin{array}{l}\text { Dominant by errors in grouping ideas and } \\
\text { the structure is unclear. }\end{array}$ \\
\hline Very poor & $0-15$ & $\begin{array}{l}\text { Virtually no mastery in writing orderly and } \\
\text { logically. }\end{array}$ \\
\hline
\end{tabular}

(Depdikbud, 1999:6)

\section{Data Analysis on Pre-test and Post-test}

The pre-test scores were statistically analyzed by using the formula of normality distribution and t-test. Data analysis on post-test employed exactly the same steps as in the pre-test data analysis.

First, determine the independent $\mathrm{t}-$ test. The steps in calculating independent $\mathrm{t}$-test were: setting the hypothesis, $\mathrm{H}_{1}$ : there is a significant difference of means between the control and experimental groups. The formula in calculating independent t-test is:

$$
t=\frac{\overline{x_{1}}-\overline{x_{2}}}{\sqrt{\left(\frac{S S_{1}+S S_{2}}{n_{1}+n_{2}-1}\right)\left(\frac{1}{n_{1}}+\frac{1}{n_{2}}\right)}}
$$

(Gay, $1998: 327)$

$$
\begin{aligned}
& \text { where } S S_{1}=\Sigma x_{1}^{2}-\frac{\left(\Sigma x_{1}\right)^{2}}{n_{1}} \text { and } S S_{1}=\Sigma x_{2}^{2}-\frac{\left(\Sigma x_{2}\right)^{2}}{n_{2}} \\
& \mathrm{X}_{1}=\text { Score of experimental group } \\
& \mathrm{x}_{2} \quad=\text { Score of control group } \\
& \bar{x}_{1} \quad=\text { Mean of experimental group } \\
& \bar{x}_{2} \quad=\text { Mean of control group } \\
& \mathrm{n}_{1} \quad=\text { Number of subject of experimental group } \\
& \mathrm{n}_{2} \quad=\text { Number of subject of control group } \\
& \text { SS } \quad=\text { Sum of Squares }
\end{aligned}
$$

The next was comparing the value of $t$ with $t$ table (see appendix 4). The writer selected $p=0,05$ then determined the appropriate degrees of freedom by using $\mathrm{n}_{1}+\mathrm{n}_{2}-2$. If $\mathrm{t}$ ratio $>\mathrm{t}$ table, it means that the hypothesis is not rejected, there is a significant difference between two groups. In contrary, If $\mathrm{t}$ ratio $<\mathrm{t}$ able, the hypothesis is rejected, there is no significant difference between the two groups (Coolidge, 2000). 
The last was percentage ( $\%$ ) of the students' development in understanding the rules of writing identified by using the following formula:

$$
\%=\frac{X_{2}-X_{1}}{X_{1}} \times 100
$$

Where:

$\%$ : Percentage of the students' development

$\mathrm{X} 1$ : The mean score of pretest

$\mathrm{X} 2$ : The mean score of posttest

\section{FINDING AND DISCUSSION}

\section{Finding}

\section{A. Findings}

The result of data analysis found that teaching writing using Mistake Buster Technique can improve the students' writing skill in term of variables of writing at the Second Grade of SMPN 33 Makassar.

\section{The Effectiveness of Mistake Buster Technique Used in Writing Recount Composition}

a. The Effectiveness of Mistake Buster Technique Used on Language Use in

\section{Writing Composition}

The use of Mistake Buster Technique is effective to improve the students' ability on language use in writing recount composition. It can be seen from the table 4.1.

Table 4.1. The Students' Mean Score on

Language Use

\begin{tabular}{|c|c|c|c|}
\hline No & Classes & Pre-Test & Post-Test \\
\hline 1. & Experimental Class & 11.25 & 62 \\
\hline 2. & Control Class & $\mathbf{8 . 2 5}$ & 47.25 \\
\hline
\end{tabular}

The table above shows the mean score of experimental class and control class on Language Use in writing recount composition. Based on the table, it indicates that the use of Mistake Buster Technique in teaching and learning language use in writing recount composition is successful. The result of the mean 
score in pretest and posttest above, where the students' mean score of experimental class in pre-test on language use is 11.25 and in post-test is 62 . While the students' mean score of control group in pre-test on language use is 8.25 and in post test is 47.25 .

Based on the table 4.1, the condition of both classes can be seen on the chart 4.1:

\section{Chart 4.1 Mean Score of Experimental and Control Class of Post-Test on Language Use}

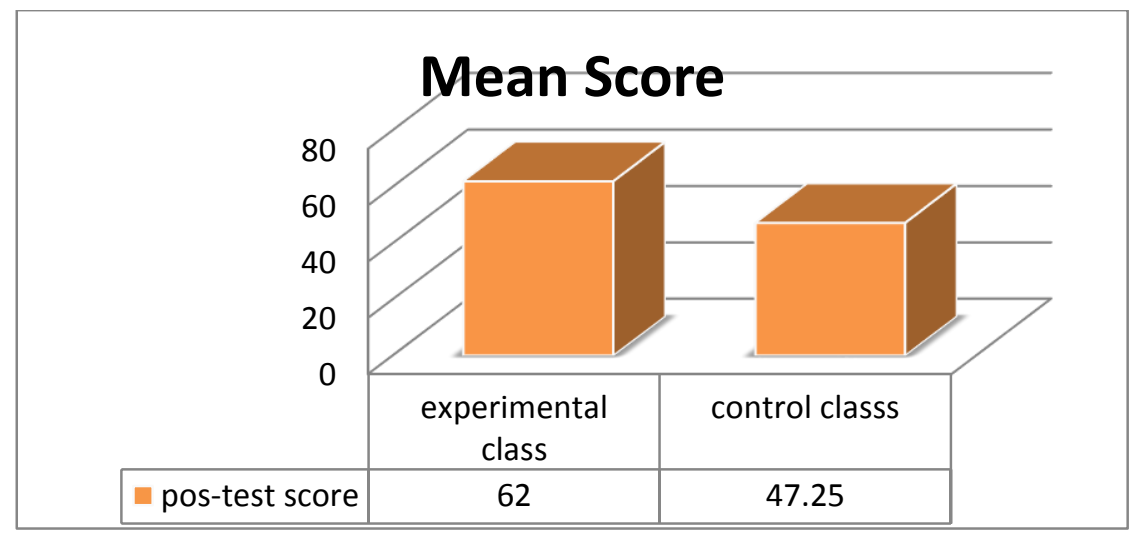

The chart 4.1 shows that the means of both experimental and control classes are significantly different. Mean score of experimental class is higher than mean score of control class after conducting treatment.

\section{b. The Effectiveness of Mistake Buster Technique Used on Organization in Writing Recount Composition}

The use of Mistake Buster Technique is effective to improve the students' Ability on organization in writing recount composition. It can be seen from the table 4.2 in which, it describes the students' score of organization.

Table 4.2. The Students' Mean Score on Organization

\begin{tabular}{|c|c|c|c|}
\hline No & Classes & Pre-Test & Post-Test \\
\hline 1. & Experimental Class & 9 & 69 \\
\hline 2. & Control Class & 10.5 & 35 \\
\hline
\end{tabular}

The table 4.2 shows the mean score of experimental class and control class on organization in writing recount composition. Based on the table, it indicates 
that the use of Mistake Buster Technique in teaching and learning organization in writing recount composition is successful. The result of the mean score in pretest and posttest above, where the students' mean score of experimental class in pretest on organization is 9 and in post-test is 69. While the students' mean score of control group in pre-test on organization is 10.5 and in post test is 35 .

Based on the table 4.2, the condition of both classes can be seen on the chart 4.2:

\section{Chart 4.2 Mean Score of Experimental and Control Class of Post-Test on Organization}

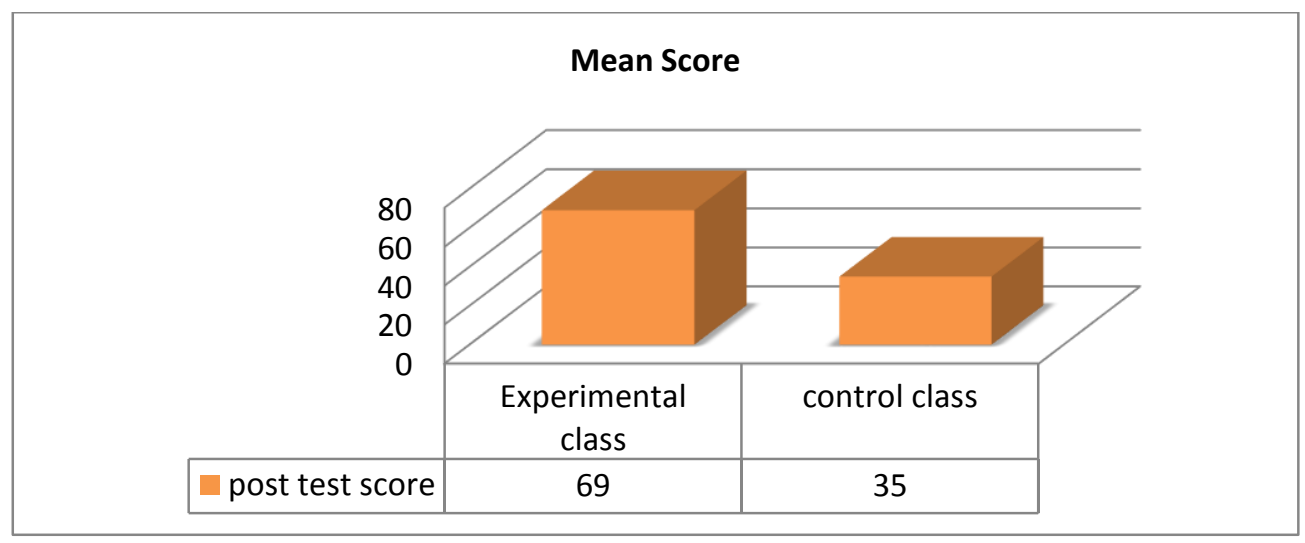

The chart 4.2 shows that the means of both experimental and control classes are significantly different. Mean score of experimental class is higher than mean score of control class after conducting treatment.

\section{The Improvement of the Students' Ability in Writing Recount Composition Using Mistake Buster Technique}

The students' ability on language use in writing recount composition in experimental class which is treated using Mistake Buster Technique is effective. The comparison between Mistake Buster Technique and Audio Visual Method has any significant difference. It can be seen from the table below in which it describes the students' score of experimental class which is treated using Mistake Buster Technique and in control class which is treated using Audio Visual Method. 
In order to see a significant difference between the result of pre-test and post-test of the students, the t-test was to be applied. The level of significance 5\% $(0.05)$ at the degree of freedom $(\mathrm{df}=\mathrm{n} 1+\mathrm{n} 2-2)=38$. The result of the calculation is shown by table 4.3 as follows:

Table 4.3.The Significant Difference of Language Use and Organization between Pre-test and Post-test

\begin{tabular}{|c|c|c|c|}
\hline $\begin{array}{c}\text { Experimental and } \\
\text { Control Class }\end{array}$ & t-test value & t-table value & Category \\
\hline Pre-Test & 0.47 & $<2.02$ & Not Significant \\
\hline Post-Test & 4.28 & $>2.02$ & Significant \\
\hline
\end{tabular}

The table 4.3 shows that, the t-test value of pre-test $(0.47)$ is smaller than $\mathrm{t}$ table value (2.02) and post-test (4.28) is higher than t-table value (2.02).

Table 4.4.The Significant Difference of Pre-test between Language Use and Organization

\begin{tabular}{|c|c|c|c|}
\hline Aspect of value & t-test value & t-table value & Category \\
\hline Language Use & 1.7 & $<2.02$ & Not significant \\
\hline Organization & -0.71 & $<2.02$ & Not significant \\
\hline
\end{tabular}

The table 4.4 shows that, the t-test value of pre test on language use (1.7) and organization (-0.71) is smaller than t-table value (2.02). Based on its result, it concludes that, the difference of both means statically not significant.

Table 4.5.The Significant Difference of Post-test between Language Use and Organization

\begin{tabular}{|c|c|c|c|}
\hline Aspect of value & t-test value & t-table value & Category \\
\hline Language Use & 2.97 & $>2.02$ & Significant \\
\hline Organization & 4.63 & $>2.02$ & Significant \\
\hline
\end{tabular}

The table 4.5 shows that, the t-test value of post test on language use (2.97) and organization (4.63) is higher than t-table value (2.02). Based on its result, it concludes that, the difference of both means statically significant. 
Table 4.6.The Students' Mean Score of Control Class on Language Use and Organization

\begin{tabular}{|c|c|c|c|c|}
\hline No & $\begin{array}{c}\text { Aspect of Value } \\
\text { (control class) }\end{array}$ & Pre-test & Post-test & $\begin{array}{c}\text { Improvement } \\
(\%)\end{array}$ \\
\hline 1 & Language Use & 8.25 & 47.25 & $472 \%$ \\
\hline 2 & Organization & 10.5 & 35 & $233 \%$ \\
\hline \multicolumn{2}{|c|}{$\overline{\boldsymbol{X}}$} & 18.75 & 82.25 & \\
\hline $\bar{X}$ & 9.375 & 41.125 & \\
\hline
\end{tabular}

Table 4.7.The Students' Mean Score of Experimental Class on Language use and Organization

\begin{tabular}{|c|c|c|c|c|}
\hline No & $\begin{array}{c}\text { Aspect of Value } \\
\text { (experimental class) }\end{array}$ & Pre-test & Post-test & $\begin{array}{c}\text { Improvement } \\
(\%)\end{array}$ \\
\hline 1 & Language Use & 11.25 & 62 & $451 \%$ \\
\hline 2 & Organization & 9 & 69 & $667 \%$ \\
\hline \multicolumn{2}{|c|}{$\overline{\boldsymbol{X}}$} & 20.25 & 131 & \\
\hline & $\overline{\boldsymbol{X}}$ & 10.125 & 65.5 & \\
\hline
\end{tabular}

The table 4.7 shows the mean score of experimental and control class on language use and organization of the students' ability in writing recount composition. Based on the table, it indicates that the use of Mistake Buster Technique in teaching and learning writing was successful. The result of the mean score in pre-test and post-test above, where the students' mean score of control class on language use and organization in pre-test is 9.375 and in post test is 41.125, while the students' mean score of experimental class on language use and organization in pre test is 10.125 and in post test is 65.5 .

From the analysis above, the writer concludes that there is a significant difference of the students' ability in writing recount composition before and after teaching using Mistake Buster Technique. It means that Mistake Buster Technique is good and suitable to be used in teaching recount composition at the Second Grade of SMPN 33 Makassar. 


\section{B. Discussion}

\section{The Effectiveness of Mistake Buster Technique Used in Writing Recount} Composition

\section{a. The Effectiveness of Mistake Buster Technique Used on Language Use in}

Based on the table 4.1, it indicates that the use of Mistake Buster Technique in teaching and learning language use in writing recount composition is successful. Based on the chart 4.1, it indicates that the mean score of experimental class is higher than mean score of control class on language use after conducting treatment.

The students' mean score of experimental class on language use in pre-test is 11.25 and post-test is 62. While the students' mean score of control class on language use in pre-test is 8.25 and post-test is 47.25 . It indicates that mean score in post-test is higher than mean score in pre-test. On the other word, the result of t-test value (2.97) is greater than t-table value (2.02).

The improvement of language use also can be seen from their writing product. The experimental group's score in language use aspect improve significantly. In regard with the improvements generic structures (using simple past tense, using to be (was, were), using adjective, noun,verb, and using adverb.

When selected and implemented appropriately as teaching technique, Mistake Buster Technique offers many advantages. First, the teacher is easy to master a class, second, easy to implement and prepare, third, can be followed by the number of students very much, this is a fresh and fun way to deal with material that tends to dry, activity that uses auditory, visual, and kinesthetic, understanding of students is tested, with around the room, the lecturer easily sees where the confusion and uncertainty arise. In addition according to Huynh (2003) by switching the role of the "mistake corrector" we will observe the students get excited. The level of excitement is even increased when the class is divided into two each other in finding and correcting the mistakes.

Furthermore, another benefit is the students have the opportunity to identify the possible mistake themselves instead of the teacher telling them what the mistakes are, thus giving them a sense of accomplishment. This Technique can 
also help the teacher checks the students' understanding of grammar point or comprehension of a reading task. It can be used to reinforce and improve their production skill such as writing and pronunciation. Last but not least, it is nonthreatening and fun which is one the best conditions for learning to take place. For this reason, it is very important for the teacher to know how to teach Language Use enjoyable and exciting. So students will interest to study. Thus, the alternative ways to teach language use in simple past tense the writer offers one of media which is used writing class. It is teaching language use by making the students as mistake correctors.

\section{b. The Effectiveness of Mistake Buster Technique Used on Organization in Writing Recount Composition}

The use of Mistake Buster Technique in teaching and learning organization in writing English sentences is successful. In which the students' mean score of experimental class on organization in pre-test is 9 and post-test is 69 . While the students' mean score of control class on organization in pre-test is 10.5 and posttest is 35. It indicates that mean score in post-test is higher than mean score in pretest. On the other word, the result of t-test value (4.63) is greater than t-table value (2.02).

The improvement of students' ability on organization revealed from the use of time order words in writing recount composition on pre-test and on posttest. On pretest, most students in both groups did not use time order words. After treatments, the students in experimental group gave some progressions in terms of their time order usage. Moreover, they could select the correct time order when they arranged paragraphs.

\section{The Improvement of the Students' Ability in Writing Recount}

\section{Composition Using Mistake Buster Technique}

The students' ability in writing recount composition in experimental class which is treated using Mistake Buster Technique is effective. Based on the table 4.3, it indicates that there is any significant difference of language use and organization between pre-test and post-test. The t-test value of pre-test (0.47) and post-test (4.28) is higher than t-table value (2.02).Thus, the difference of language 
use and organization means statically significant. Based on the table 4.5, the t-test value of post test on language use (2.97) and organization (4.63) is higher than ttable value (2.02). Based on its result, it concludes that, the difference of both means statically significant.

Based on the table 4.6 and 4.7, it indicates that the use of Mistake Buster Technique in teaching and learning writing was successful. Where the students' mean score of control class on language use and organization in pre-test is 9.375 and in post test is 41.125 , while the students' mean score of experimental class on language use and organization in pre test is 10.125 and in post test 65.5.

And based on the table 4.3, it indicates that t-test value is higher than t-table value. There is a significant difference between the mean score of post-test (62.5) and the mean score of pre-test (10.125). In addition, the t-test is greater than $\mathrm{t}$ table that is $4.28>2.02$. Therefore the null hypothesis $(\mathrm{Ho})$ is rejected, while the alternative hypothesis is accepted.

This research was aimed at investigating whether the use of Mistake Buster Technique significantly improved students' ability in writing recount composition. The writing test in pretest and posttest was used as the instrument in this study. Furthermore, t-test formula was used to compute the pretest and posttest score. Besides, the students' pretest data were analyzed to know the initial ability in writing recount composition and to measure the equity between experimental and control group before the treatment. Having received some treatments, the posttest was administered to the experimental and control group. This test was intended to measure whether Mistake Buster Technique can help students improve their writing ability in writing recount composition. The posttest computation result showed that the findings may be concluded that the two aspects in writing assessment on language use and organization, have significantly improved (value of $t(4.28)$ is bigger than the ratio on t table $(2,02)$. Thus, the alternative hypothesis was not rejected which means that there were significant differences between the experimental and control groups' scores after treatment. From the explanation above, it can be drawn a conclusion that the students who 
receive the treatment have significant improvement mainly in language use and organization. The writing assessment was adopted from Depdikbud (1999).

The result of the calculation of t-test on pretest (see appendix 4.a) is 0,47 . In the $\mathrm{t}$ table (see appendix 6) for $\alpha=0,05 d f=38 \mathrm{t}$ ratio is 2,02. The data shows the data from the experimental and control groups are equal with the value of $t$ is lower than table $(0,47<2,02)$. It indicates that the alternative hypothesis is rejected; there was no significant difference between the data of the two groups. This result implies that the experimental and control group are similar in their initial ability.

The result of the calculation of t-test on posttest (see appendix 4.a) is $4.28 \mathrm{t}$ table (see appendix 6) for $\alpha=0,05 d f=38 \mathrm{t}$ ratio is 2,02. Based on the calculation, the value of $\mathrm{t}$ is bigger than the ratio on $\mathrm{t}$ table, $4.28>2.02$. According to the result, it can be concluded that the alternative hypothesis is not rejected. There was a significant difference between students who are assigned by the use of Mistake Buster Technique and students who are not.

The only way to improve writing skill is writing practice. Thus, in every meeting the students are exposed to write and teacher gave the feedback on their writing so that it enables them to memorize how to write the recount composition in correct language use and well organization. Writing is like swimming, it is learned behaviors (Brown, 2001:335) and it inferred that writing needs practice (Alwasilah, 2000 p.108). Supporting opinion about teacher feedback was also argued by Harmer (2002) teacher's feedback on students' writing is one of the ways that can encourage students to write and correct their mistakes. In short, teacher's feedback is also important to improve students' writing ability.

In cope with the use of Mistake Buster Technique to improve the students' ability in writing recount composition, almost all students gave positive perception. Dealing with motivation, the students did not feel learning English as a frightening and boring subject and the learning atmosphere in classroom was also more fun and challenging (Stlempleski et al.2000). In regard to the functions of Mistake Buster Technique as teaching technique that gives benefit to students learning and students inspired to write. 
Looking at the comparison of the students' pre-test and post-test in mean score and t-test result, the writer can conclude that the use of Mistake Buster Technique can help the students in improving their ability in writing recount composition. From the analysis above, there is a significant difference of the students' ability in writing recount composition before and after teaching using Mistake Buster Technique. It means that Mistake Buster Technique is good and suitable to use in teaching recount composition at the Second Grade of SMPN 33 Makassar.

\section{CONCLUSION AND SUGGESTION}

\section{Conclusion}

Based on the result of data analysis and discussion of the result in the previous chapter, the writer concluded that:

1. The use of Mistake Buster Technique was effective on language use and organization in writing recount composition. It was proved by the data after being using Mistake Buster Technique which the mean score of experimental and control class on language use in pre-test were 8.25 and 11.25 and post-test were 47.25 and 62 . Then, the mean score of experimental and control class on organization in pre-test were 10.5 and 9 and post-test were 35 and 69.

2. The use of Mistake Buster Technique improved the students' ability on language use and organization in writing recount composition. It was proved by the comparison between Mistake Buster Technique and Audio Visual method has any significant difference. It was shown by the significant difference between the progresses in writing of the students who were studying through Mistake Buster Technique and those were not. The t-test value of pre-test (0.47) and post-test (4.28) was higher than t-table value (2.02).

\section{Suggestions}

Based on the conclusion presented in the previous, the writer tries to give some suggestions for the future research about the English teaching technique as follows: 
1. It is suggested to the English teachers to apply Mistake Buster Technique as one of alternative Technique in teaching recount composition.

2. It is suggested to the English teachers to invite the students to use Mistake Buster Technique in learning process to improve their ability in writing recount composition.

\section{REFERENCE}

Alwasilah, A. Chaedar. 2000. Perspective Pendidikan Bahasa Inggris di Indonesia Dalam Konteks Persaingan Global. Bandung: Andira.

Arikunto, Suharsimi. 1993. Prosedur Penelitian: Suatu Pendekatan Praktis. Jakarta: PT. Rineka Cipta.

Broughton, Christopher, Roger, Peter, and Anita. 1975. Teaching English as a Foreign Language. London and New York: Routledge and Kegan Paul.

Brown, H. Douglas. (1994). Teaching by Principles: an Interactive Approach to Language Pedagogy. New Jersey/United State of America: Prentice Hall Regents, Inc.

Brown,H Douglas. 2001. Teaching by Principles: An Interactive Approach to Language Pedagogy (Second Edition). San Francisco, California: Addison Wesley Longman Inc.

Brummer, T., \& Clark, K., S. 2008. Writing Strategies for mathematics [Electronic Version]. Shell Educations 30 (4), 1-99.

Byrne, Donn. 1980. Teaching Writing Skills. Longman Handbooks for Language Teacher.

Dagher, P. J. 1976. Writing Practical Guide. Houghton Mifflin Company. USA.

Depdikbud. 1999. Penyempurnaan Kurikulum Bahasa Inggris 1994. Jakarta: Depdikbud.

Derewianka, Beverly. (2004). Exploring How Texts Work. Australia: Primary English Teaching Association.

Donn, Byrne. 1988. Teaching writing skill. London: Longman group ltd.

Frank, Marcella. 1972. Modern English: a Practical Reference Guide. New Jersey: Prentice-Hall, Inc. Englewood Clift's.

Gay, L.R. 1981. Educational Research Competencies for Analysis and Application. Columbus: Merril Publishing Company. 
Harris, P, David. 1969. Testing English as A Second Language. New York. Megrawa Hill book Company.

Harmer, J. 1991. The Practical of English Language Teaching. London: Longman Group.

Hasanah. (2012). The Mastery of Simple Past Tense of the Eighth Grade Students of MTs Matholiul Ulum Banjaragung bangsri Jepara in Academic Year 2011/2012 Taught by Using Mistake Buster Technique.

Heaton, J. B. 1975. Writing English Language Test. London; Longman Group.

Huynh. Hai. K. P. 2003.Getting Students Actively Involved Using "The Mistake Buster" Technique. The Internet TESL Journal. Volume IX, No. 11. (http://iteslj.org/Techniques/Hyunh-MistakeBuster.html, 2 Mei 2014)

Jacob, H. Z. Z. Z. A, Stephan M. R, Reanna H.V, Faye H. B, and Jane. 1981. Testing ESL (Composition, a practical Massachusetts). New Burry House Publisher.

Kreidler, Carol, J.1965. Visual Aid for Teaching English to the Speakers of Other Languages. Washington D.C. Center for Applied Linguistics.

Leo, dkk. 2007. English for Academic Purpose: Essay Writing. Yogyakarta: C.V Andi Offset.

Littell, Joy. 1981. Basic Skill in English. New York: McDougal. Littell \& Company.

Maezida, Azizatin Nida. (2013). The Simple Past Mastery of the Eight Grade Students of Mts NU Muallimat Kudus in the Academic Year 2012/2013 Taught by Using Mistake Buster Technique.

Norrish, J. 1992. Language Learners and Their Errors. London: Macmillan Publishers.

Pardiyono. 2007. Pasti Bisa!! Teaching Gender-Based Writing. Yogyakarta: C.V. Andi Offset.

Ratminingsih, Ni made. (2007). Mistake Buster Technique in learning Grammar: Improving Grammar Mastery and students' Participation at the First Grade of SMPN 1 Sukasada. http://www.pasca.undiksha. Accessed on 30 May 2014.

Sarlin, M. T. 2009. The Effectiveness of Peer Response in Writing Process to Improve Students' Writing Ability. A thesis FKIP Unismuh Makassar.

Sokolik, Maggie. 2003. Practical English Language Teaching. New York: McGraw-Hill 
Sudjana, Nana. 2005. Dasar-dasar Proses Belajar Mengajar . Bandung: Sinar Baru Algesindo.

Sugiyono, 2007. Metode Penelitian Kuantitatif, Kualitatif dan $R \&$ D. Bandung: Alfabeta.

Surahmad, Winarno. 1985. Pengantar Penelitian Ilmiah. Bandung: Tarsito.

Stlempleski et al. 2000. Card in English classroom for Motivation and Interest. [Online]. Available at: http://www.kotesol.org/?q=node/179 [June 28th, 2012].

Thomson, A. J and Martinet, A. V. 1995. A Practical English Grammar. Hong Kong: Oxford University Press.

Yulia, Wilma. 2014. Example of Regular and Irregular Verbs and Meaning. http://www.cws.illinois.edu/workshop/writers/irregularverbs/regular verb. Accessed on 27 May 2014. 